\title{
Feasibility of Small Autonomous Solar Powered Water Desalination Units for Arid Regions
}

\author{
Mohamed Azab* and Mohamed Naser Al-Ghamdi
}

\author{
Center for Renewable Energy-Research Center, Colleges \& Institutes Sector, RC Yanbu, Saudi Arabia
}

\begin{abstract}
The main objective of this work is to conduct a feasibility study of utilizing small autonomous water desalination units powered by photovoltaic modules as a green renewable energy resource to be employed in different isolated zones as a source of drinking water for some scattered societies where the installation of huge desalination stations are discarded owing to the unavailability of electric grid in remote areas. Yanbu City is chosen as a case study where the Renewable Energy Center exists and equipped with all sensors to assess the availability of solar energy all over the year. The study included two types of available water: the first type is brackish well water and the second type is seawater of coastal regions. In the case of well water, two versions of desalination units are involved in the study: the first version is based on day operation only. While the second version takes into consideration the night operation, which requires energy storage system as batteries to provide the necessary electric power at night. According to the feasibility study results, it is found that utilization of small autonomous desalinations unit is applicable and economically accepted in the case of brackish well water. However, in the case of seawater the capital costs are extremely high and the cost of desalinated water will not be economically feasible unless governmental subsidies are provided.

In addition, the study indicated that, for the same water production, the utilization of energy storage version (day-night) adds additional capital cost for batteries, and extra running cost for their replacement, which makes the unit price not only incompetent with day-only unit but also with conventional units powered by diesel generator (fossil fuel) owing to the low prices of fuel in the kingdom. However, the cost analysis shows that the price of the produced water per cubic meter of day-night unit is similar to that produced from the day-only unit provided that the day-night unit operates theoretically for a longer period of $50 \%$.
\end{abstract}

Keywords: Renewable energy, solar energy, water desalination, reverse osmosis.

\section{INTRODUCTION}

The shortage of fresh water is a major problem in several areas of the world such as arid regions and coastal zones in several countries of Arabian Gulf. Fortunately, arid regions are exposed to high levels of solar irradiation most the year, which makes the utilization of solar energy a promising solution to such problem with zero harmful emission (Green System).

A recently published study [1] shown that $85 \%$ of the world's population resides in the drier half of the Earth. In addition, more than 1 billion people living in arid and semi-arid parts of the world have access to little or no renewable water resources. Many arid regions in Middle East suffer from fresh water scarcities. The problem has either a quantitative nature (scarce of water) or a qualitative nature (low water quality) [2]. The foreseen growth of population will make the situation more critical. Desalination of brackish or seawater can help to resolve such expected crisis. The main drawbacks of this solution are high energy consumption and high cost $[3,7]$. As arid lands are exposed to great solar irradiance, solar desalination is viable solution for remote areas and

*Address correspondence to this author at the Center for Renewable EnergyResearch Center, Colleges \& Institutes Sector, RC Yanbu, Saudi Arabia; Tel: 00 966543132750; E-mail: azabm@rcyci.edu.sa small communities in arid and semi-arid regions [4]. Innovation has accelerated in response to recent public and political pressure to reduce greenhouse gas emissions thought to be contributing to global climate change [5]. The use of renewable energy resources has risen worldwide with technical innovation lowering costs. On the other hand, investment in safe drinking water and sanitation contributes to economic growth. For each \$1 invested, the World Health Organization (WHO) estimates returns of $\$ 3-\$ 12$, depending on the region and technology [5].

\section{POTENTIAL OF SOLAR ENERGY IN YANBU CITY}

The first step in the feasibility study is to assess the potential of solar energy in the selected zone. In this study Yanbu city is intentionally chosen to assess the potential of solar energy as the Renewable Energy Center is equipped with the necessary measuring devices. Generally, Saudi Arabia is one of the Middle East countries that are exposed to enormous levels of solar irradiance all over the year. In the renewable energy center, the instantaneous values of solar irradiance and temperature are measured every two minutes. The stored data for one year (September 2013-August 2014) are tabulated and some of them are illustrated in Figures 1-4. According to the obtained data, Yanbu is exposed to considerable levels of solar irradiance all over the year. The maximum values every 
month are plotted in Figure 1, while the monthly average values are plotted in Figure 2. The registered annual average value of solar irradiance is $260 \mathrm{~W} / \mathrm{m}^{2}$. While the annual mean value of the registered monthly maximum values is $1135 \mathrm{~W} / \mathrm{m}^{2}$ which exceeds the standard test conditions $\left(1000 \mathrm{~W} / \mathrm{m}^{2}\right)$. One of the daily solar irradiance is plotted in Figure 3. According to the obtained data, the availability of the solar irradiance is not less than 8 hours daily. However, the measured data of temperature at PV surface reaches to high levels up to 50 degree or more. This should be taken into consideration in the design phase and selection of proper rating of $\mathrm{PV}$ modules.

Monthly average and maximum values of solar irradiance

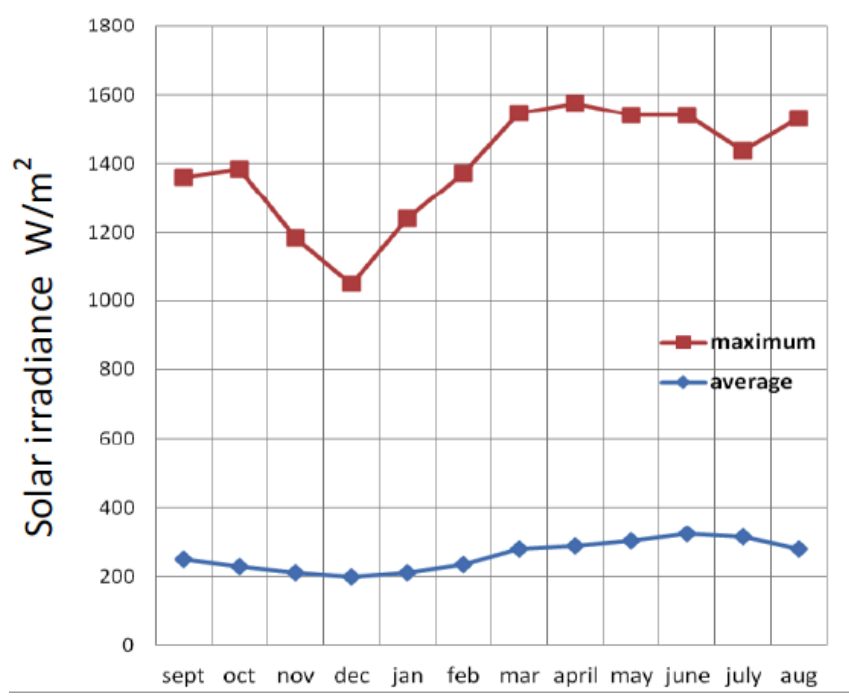

Figure 1: Monthly average and maximum values of solar irradiance in Yanbu from September 2013 till august 2014.

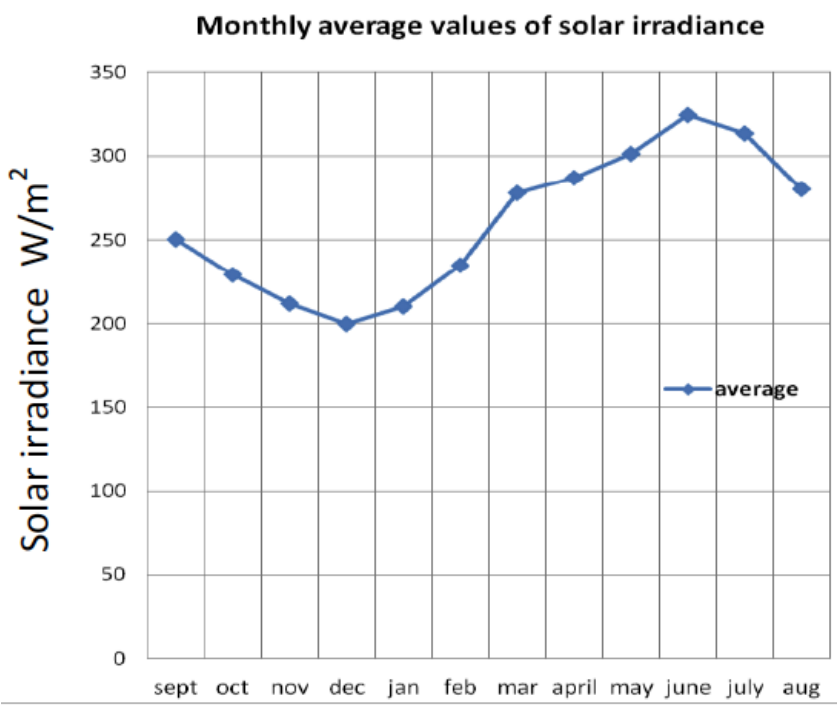

Figure 2: Monthly average values of solar irradiance in Yanbu from September 2013 till August 2014.

\section{Daily solar irradiance}

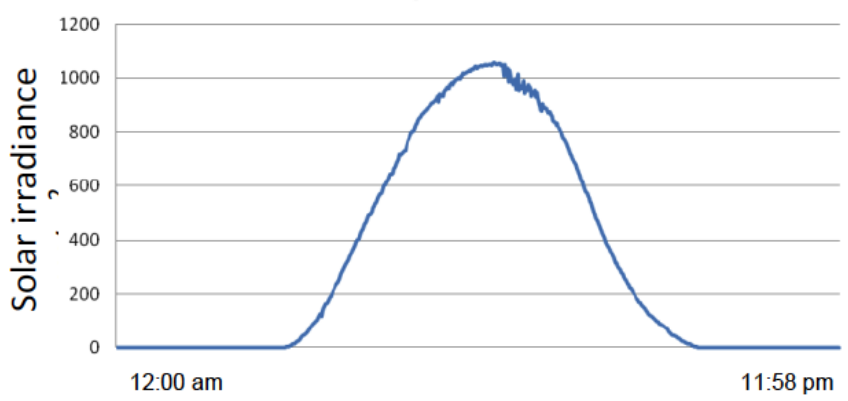

Figure 3: Daily measured solar irradiance in Yanbu (11 June 2014).

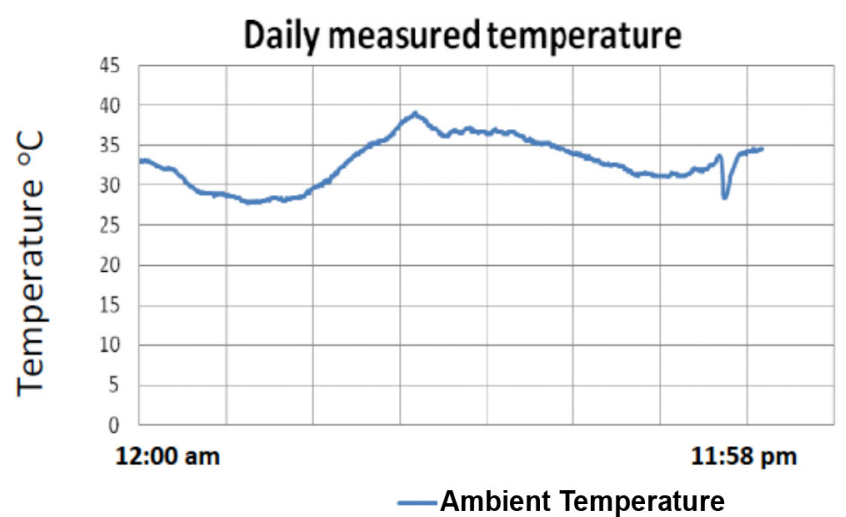

Figure 4: Daily measured temperature in Yanbu (11 June 2014).

\section{Reverse Osmosis Desalination Technique}

Fresh water desalination plants are based on the following techniques: multistage flash (MSF), vapor compression (VC), electro dialysis (ED) and reverse osmosis (RO) [6]. Among these methods, RO is currently considered as the most attractive process to produce fresh water from both brackish and sea water [2]. The salient advantage of RO over others is in lower energy consumption. Table 1 presents typical energy consumptions of the most common desalination processes based on the results presented in [10].

Table 1: Energy Consumption of Different Desalination Processes

\begin{tabular}{|c|c|c|}
\hline \multirow{2}{*}{ Feed Water } & $\begin{array}{c}\text { Desalination } \\
\text { Process }\end{array}$ & $\begin{array}{c}\text { Electric Energy } \\
\mathbf{( k W h / \mathbf { m } ^ { 3 } )}\end{array}$ \\
\hline \hline \multirow{2}{*}{ Seawater } & MSF & $3.5-5$ \\
\cline { 2 - 3 } & MED & $1.5-2.5$ \\
\hline $\begin{array}{c}\text { Brackish water, } \\
\text { TDS: } 1500-3500 \\
\text { ppm }\end{array}$ & RO (brackish) & $0.5-2.5$ \\
\cline { 2 - 3 } & RO (seawater) & $5-9$ \\
\cline { 2 - 3 } & ED & $2.5-5.5$ \\
\hline
\end{tabular}


Reverse Osmosis is a separation phenomenon, which separates fresh water from seawater or brackish water through semi-permeable membranes by applying a high pressure (HP) to the salty (saline) water to overcome the osmotic pressure (OP), and forces the water to flow from the concentrated medium to the dilute side through the membrane as illustrated in Figure 5.

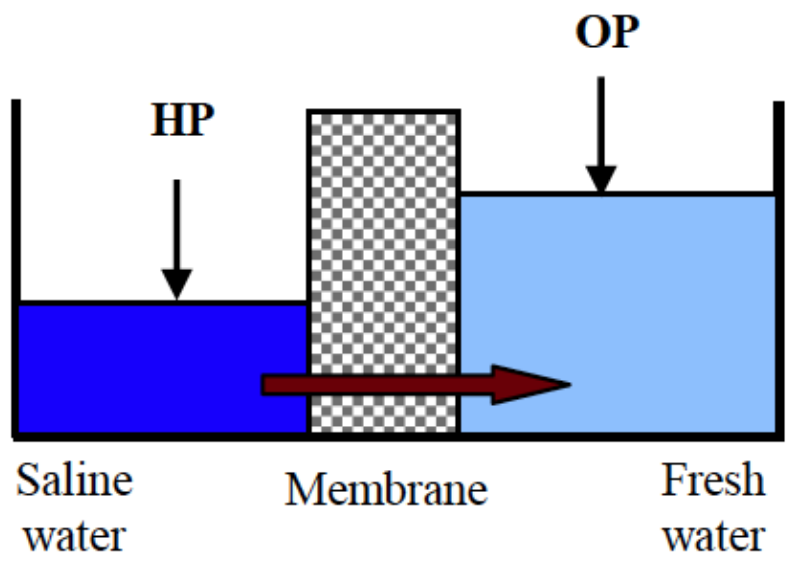

Figure 5: Principle of reverse osmosis: HP > OP.

A typical RO desalination plant essentially consists of four major systems: 1- Pretreatment, 2- Highpressure pump, 3- Membrane assembly, 4- Posttreatment.

A simplified block diagram of RO hydraulic system is shown in Figure 6. As a portion of the water passes through the membrane, the remaining feed water increases in salt content. At the same time, a portion of this feed water is discharged without passing through the membrane. The amount of the feed water discharged to waste in the brine stream varies from 20 to $70 \%$ of the feed flow, depending on the salt content of the feed water, pressure, and type of membrane.

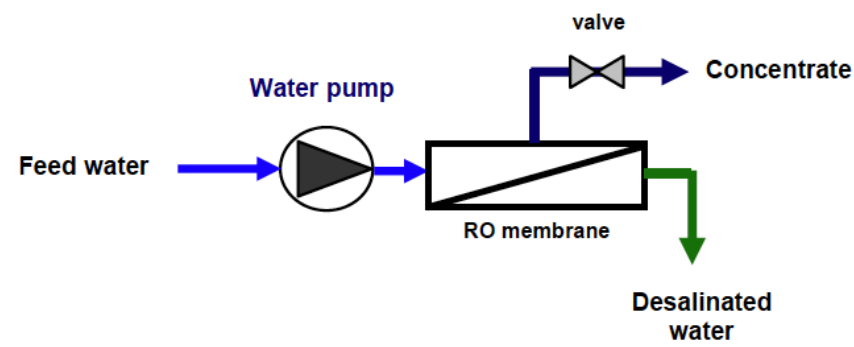

Figure 6: Block diagram of simplified RO water desalination system.

Extensive pretreatment is usually required on the raw (saline) feed water. Thus, suspended solids must be removed and the water pretreated so that salt precipitation or microbial growth does not occur on the membranes. Usually, the pretreatment consists of fine filtration and the addition of acid or other chemicals to inhibit precipitation and the growth of microorganisms. The high-pressure pump supplies the pressure needed to enable the water to pass through the membrane and have the salts rejected. Pressurizing the saline water accounts for most of the energy consumed by RO.

\section{PRINCIPLES OF PV CELLS}

A solar cell basically is a $p-n$ semiconductor junction. When exposed to light, a dc current is generated. The light-generated current varies linearly with the solar irradiance. PVs offer several advantages such as: high reliability, low maintenance cost, no environmental pollution, and absence of noise. However, a major drawback of the PV source is its ineffectiveness during low irradiance periods or during partially shaded conditions $[8,11]$. The equivalent circuit of the PV cell is shown in Figure 7, where light dependent current source is parallel to the $P N$ structure. In addition, there a small series resistance and high resistance parallel to the PN structure.

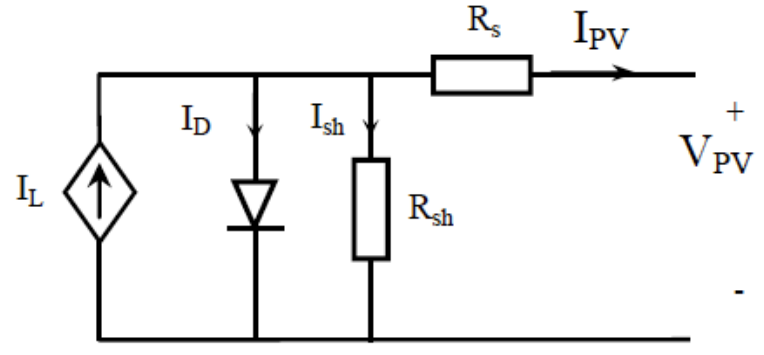

Figure 7: Equivalent circuit of PV solar cell.

Equations (1) and (2) are used to describe the characteristics of a single PV Cell.

$I_{P V}=I_{L}-I_{o}\left(e^{q\left(V_{P V}+I_{P V} R_{S}\right) / A k T}-1\right)-\frac{V_{P V}+I_{P V} R_{s}}{R_{s h}}$

$P_{P V}=V_{P V} \cdot I_{P V}$

Where: $I_{P V}$ is the PV module current (Amp), $I_{L}$ is the light generated current (Amp), $I_{0}$ is the diode saturation current, $\mathrm{q}$ is the charge of electron (coulomb), $\mathrm{K}$ is the Boltzmann's constant $(\mathrm{J} / \mathrm{K}), A$ is the diode factor, $T$ is the module temperature $(K), R_{s}$ is module series resistance (ohm), $R_{\mathrm{sh}}$ is module parallel resistance (ohm), $V_{P V}$ is the module output voltage (Volt), and $P_{P V}$ is the extracted PV power (Watt). In order to extract the maximum possible power from the PV system, the PV module must operate at the optimal power point. Thus, instantaneous maximum power point of PV module is 
tracked with the aid of a power electronics converter driven by a suitable MPPT algorithm $[8,11]$.

\section{BRACKISH WELL WATER DESALINATION UNIT}

\section{Description of the Overall System}

The block diagram of the desalination water system is shown in Figure $\mathbf{8}$ where the PV modules converters the sunlight into electric dc current which provides the dc pump with the necessary electric power to drive the reverse osmosis unit (RO). At the same time, PVs charges a battery bank for night operation.

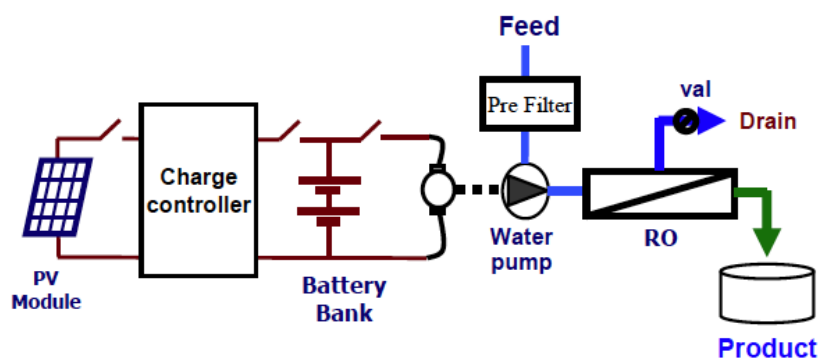

Figure 8: Block diagram of the proposed solar powered RO water desalination unit.

\section{Required Features of the RO Unit}

The RO unit should consist of 5-stages defined below:

1st stage: 5 Micron Spun Fiber Pre-filter.

2nd stage: Granular Activated Carbon filter.

3rd stage: 1 Micron Spun Fiber Pre-filter.

4th stage: RO Membrane.

5th stage: Post Activated Carbon filter.

A dc pump of 75-100 watt is recommended.

A storage tank should be provided also.

Minimum water production is $2 \mathrm{~L} / \mathrm{min}$.

As the rating of the system is small, the dc pump is selected instead of ac pump in order to reduce the initial cost of the system by eliminating the dc-ac inverter.

\section{Choice of the PV Module}

A single module of 200 Watt peak is suitable to provide the necessary power to the unit. Or $2 \times 100$ Watt Peak PV modules connected in series can do the same function taking into consideration the high ambient and $\mathrm{PV}$ temperatures that requires over sized rating at least $25 \%$ higher than its rating at standard test conditions $\left(25^{\circ} \mathrm{C}\right)$. In order to reduce the system cost, sun tracking system will not be installed. Therefore, the optimum tilt angle for fixed PV modules should be taken into consideration. According to Yanbu latitude angle $\left(23.98^{\circ}\right)$, the optimum tilt angle is $20^{\circ}$.

\section{Power Electronic Converter}

A Step down dc chopper of 300-400 Watt should be connected between the PV and the dc pump to provide the pump with the suitable voltage level. In addition, a maximum power point tracking feature should be incorporated with the chopper control unit to extract the maximum possible power from the PV module.

\section{Cost Analysis}

\section{Version A (day operation only: no storage system)}

\section{Capital costs}

A detailed cost analysis of the initial (capital) cost of the proposed desalination unit is indicated in Table 2 based on the current prices of local market. The total cost is $4100 \mathrm{SR}$. The unit price can be reduced in the case of mass production.

Table 2: Summary of Capital Cost of Version A

\begin{tabular}{|c|c|}
\hline Item & Cost (SR) \\
\hline \hline PV module & 1600 \\
\hline RO unit and accessories & 1000 \\
\hline $\begin{array}{c}\text { Chopper power circuit and its } \\
\text { electronic control unit }\end{array}$ & 800 \\
\hline PV support and unit cabinet & 500 \\
\hline Installation \& Miscellaneous & 200 \\
\hline Total capital cost (SR) & $\mathbf{4 1 0 0}$ \\
\hline
\end{tabular}

\section{Running Costs}

There will be annual running cost. Some of the RO filters need replacement every (six-months). Others need replacement every ( 1 year) according to the manufacturer data sheet. Therefore, the dominant yearly cost is the replacement of the membranes. The average annual expenditure to replace such items is estimated to be $200 \mathrm{SR}$.

The PVs do not need maintenance and its life is 20 years. Cleaning the surface of PV module is essential to prevent dust accumulation. This can be done weekly in the early morning. The booster pump life is 3 years. Assume the life time of the chopper is 5 years. If the 
total life of the unit is 10 years, so the pump should be replaced every 3 years, and the chopper should be replaced once. As the system is not complicated, the labor costs are nil.

Table 3: Summary of Running Cost of Version A

\begin{tabular}{|c|c|}
\hline Item & Cost (SR) \\
\hline \hline Filters (annually) & $9 \times 200$ \\
\hline Pump (three years) & $3 \times 200$ \\
\hline Chopper and control unit (5 years) & $1 \times 800$ \\
\hline PV maintenance & 0 \\
\hline Total running cost (SR) & $\mathbf{3 2 0 0}$ \\
\hline
\end{tabular}

\section{Water Production Cost Per Cubic Meter}

The total life cost of the implemented unit is computed based on 10 years of operation. As the unit produces at least $2 \mathrm{~L} / \mathrm{min}$. Assume that the unit operates 8 hours Therefore, the annual water production is $350 \mathrm{~m}^{3}$. While the life cycle water production is $3500 \mathrm{~m}^{3}$. An estimate of cost per cubic meter is presented in Table 4. The estimated cost per cubic meter based on 10 years of operation is $2.08 \mathrm{SR}$.

Table 4: Life Cycle and Water Production Costs of Version A

\begin{tabular}{|c|c|}
\hline Item & Cost (SR) \\
\hline \hline Annual water production $\left(350 \mathrm{~m}^{3}\right)$ & \\
\hline Total amount of water production $\left(3500 \mathrm{~m}^{3}\right)$ & \\
\hline Capital costs & 4100 \\
\hline Total running costs & 3200 \\
\hline Total life cycle costs & 7300 \\
\hline Cost per cubic meter & $2.08 \mathrm{SR}$ \\
\hline
\end{tabular}

The estimated cost of $2.08 \mathrm{SR} / \mathrm{m}^{3}$ is satisfactory if we take into consideration the price of commercially available items is dramatically reduced in the case of mass production. Under governmental subsidies, the cost would be reduced below that estimated value. However, in the case of isolated arid zones, this system is promising and effective for safe drinking water.

\section{Version B (day and night operation: storage system included)}

\section{Capital Costs}

In this version, a battery bank ( $2 \times 12 \mathrm{~V}$ batteries) is needed for night operation, also the PV size is increased to be able to supply the pump and charge the batteries simultaneously. One additional PV module is assigned for the battery charging. Also, a charge controller is required with MPPT capability is required. A detailed cost analysis of the initial (capital) cost of the proposed desalination unit is indicated in Table 5 based on the current prices of local market. The total cost is $5400 \mathrm{SR}$. The unit price can be reduced in the case of mass production.

Table 5: Summary of Capital Cost of Version B

\begin{tabular}{|c|c|}
\hline Item & Cost (SR) \\
\hline \hline PV module & 2400 \\
\hline RO unit and accessories & 1000 \\
\hline Charge controller & 800 \\
\hline Batteries & $2 \times 250$ \\
\hline PV support and unit cabinet & 500 \\
\hline Installation \& Miscellaneous & 200 \\
\hline Total capital cost (SR) & $\mathbf{5 4 0 0}$ \\
\hline
\end{tabular}

\section{Running Costs}

The annual cost will be similar that of version $A$. Except the replacement cost of batteries every 2 years. The charge controller life is assumed to be 5 years that will be replaced once.

Table 6: Summary of Running Cost of Version B

\begin{tabular}{|c|c|}
\hline Item & Cost (SR) \\
\hline \hline Filters (annually) & $9 \times 200$ \\
\hline Pump (three years) & $3 \times 200$ \\
\hline Charge controller (5 years) & $1 \times 800$ \\
\hline Replacement of batteries & $4 \times 500$ \\
\hline PV maintenance & 0 \\
\hline Total running cost (SR) & $\mathbf{5 2 0 0}$ \\
\hline
\end{tabular}

\section{Water Production Cost Per Cubic Meter}

The total life cost of the implemented unit is computed based on 10 years of operation. As the unit produces at least $2 \mathrm{~L} / \mathrm{min}$. Assume that the unit operates 10 hours Therefore, the annual water production is $438 \mathrm{~m}^{3}$. The total life cycle water production is $4380 \mathrm{~m}^{3}$. An estimate of cost per cubic meter is presented in Table 7. The estimated cost per cubic meter based on 10 years of operation is $2.42 \mathrm{SR}$.

The total cost looks unsatisfactory for customers with the current prices of fuel in the KSA. The 
estimated cost of the produced water is $2.42 \mathrm{SR} / \mathrm{m}^{3}$ which would be incompetent and would not get the society approval and satisfaction unless the government offers suitable subsidies.

Table 7: Life Cycle and Water Production Costs

\begin{tabular}{|c|c|}
\hline Item & Cost (SR) \\
\hline \hline Annual water production $\left(525.6 \mathrm{~m}^{3}\right)$ & \\
\hline Total amount of water production $\left(5256 \mathrm{~m}^{3}\right)$ & \\
\hline Capital costs & 5400 \\
\hline Total running costs & 5200 \\
\hline Total life cycle costs & 10600 \\
\hline Cost per cubic meter & $2.42 \mathrm{SR}$ \\
\hline
\end{tabular}

Theoretically, if the unit operation time is increased to be 12 hours ( $50 \%$ longer than the version A) the cost of produced water per cubic meter is $2.01 \mathrm{SR}$ which is similar to the water cost produced by version $\mathrm{A}$ unit.

\section{SEA WATER DESALINATION UNIT}

\section{Capital Costs}

In the case of sea water the TDS (30000-40000 $\mathrm{ppm}$ ) is much higher than the TDS of well water (1000$5000 \mathrm{ppm}$ ). Therefore, it needs high pressure pumps. In addition, the water pressure across RO filters should be kept constant otherwise the RO filters will be damaged. Accordingly, in the case of seawater desalination, energy storage system is required to keep and maintain the unit pressure constant across the RO membranes all the time. Also, the PV rating is dramatically increased owing to the requirement of high pressure pumping. The number of batteries is also increased. Power electronic inverter is required to adjust the speed of motor pumps. A detailed cost

Table 8: Summary of Capital Cost of Sea Water Desal Unit

\begin{tabular}{|c|c|}
\hline Item & Cost (SR) \\
\hline \hline PV module & 15000 \\
\hline RO unit and accessories & 7000 \\
\hline Charge controller & 3000 \\
\hline Batteries & $10 \times 250$ \\
\hline PVs support and unit cabinet & 2500 \\
\hline inverter & 5000 \\
\hline Total capital cost (SR) & $\mathbf{3 5 0 0 0}$ \\
\hline
\end{tabular}

analysis of the initial (capital) cost of the proposed desalination unit is indicated in Table 8 based on the current prices of local market. The total cost is 35000 $\mathrm{SR}$. The unit price can be reduced in the case of mass production.

\section{Running Costs}

Table 9: Summary of Running Cost of Sea Water Desal Unit

\begin{tabular}{|c|c|}
\hline Item & Cost (SR) \\
\hline \hline Filters (annually) & $9 \times 800$ \\
\hline Pump (three years) & $3 \times 1500$ \\
\hline Charge controller & $1 \times 3000$ \\
\hline Replacement of batteries & $3 \times 10 \times 250$ \\
\hline PV maintenance & 0 \\
\hline inverter & $1 \times 5000$ \\
\hline Total running cost (SR) & $\mathbf{2 7 2 0 0}$ \\
\hline
\end{tabular}

\section{Water Production Cost Per Cubic Meter}

The total life cost of the implemented unit is computed based on 10 years of operation. As the unit produces at least $2 \mathrm{~L} / \mathrm{min}$. Assume that the unit operates 10 hours Therefore, the annual water production is $438 \mathrm{~m}^{3}$. While the total life cycle water production is $4380 \mathrm{~m}^{3}$.

An estimate of cost per cubic meter is presented in Table 10. The estimated cost per cubic meter based on 10 years of operation is 14.2 SR! which is completely incompetent with conventional techniques of diesel generators under the current prices of oil in Saudi Arabia.

Table 10: Life Cycle and Water Production Costs

\begin{tabular}{|c|c|}
\hline Item & Cost (SR) \\
\hline \hline Annual water production $\left(525.6 \mathrm{~m}^{3}\right)$ & \\
\hline Total amount of water production $\left(5256 \mathrm{~m}^{3}\right)$ & \\
\hline Capital costs & 35000 \\
\hline Total running costs & 27200 \\
\hline Total life cycle costs & 62200 \\
\hline Cost per cubic meter & $14.2 \mathrm{SR}$ \\
\hline
\end{tabular}

\section{SOME EXPERIMENTAL RESULTS}

In Figure 9, experimental data of a single PV module are plotted. Figure 9a shows the I-V curve of 
the single PV module while Figure $9 b$ indicates the corresponding P-V curve. According to the measured data, the PV had a peak power of 62 Watt during such atmospheric operating conditions (temperatureirradiance). The corresponding PV voltage is $16 \mathrm{~V}$ and the current at such maximum condition was $3.9 \mathrm{~A}$.

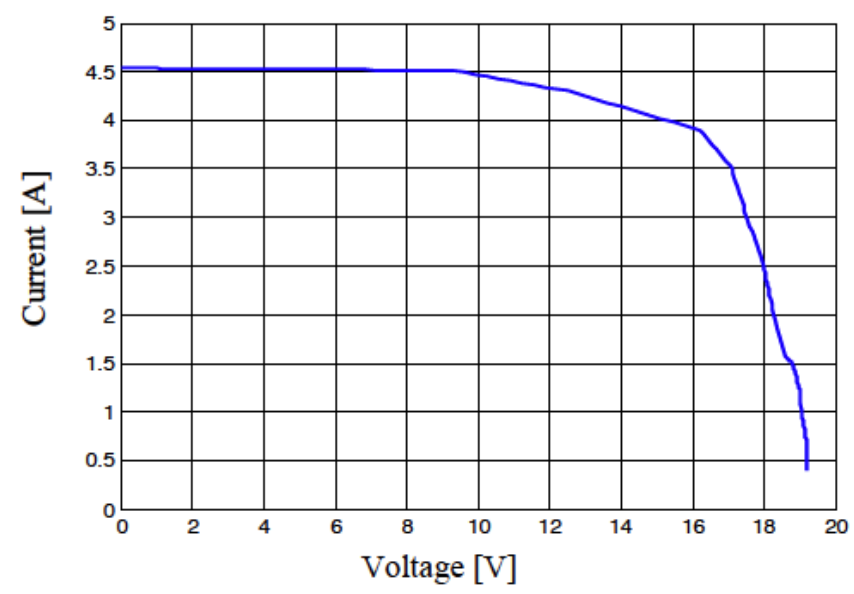

a

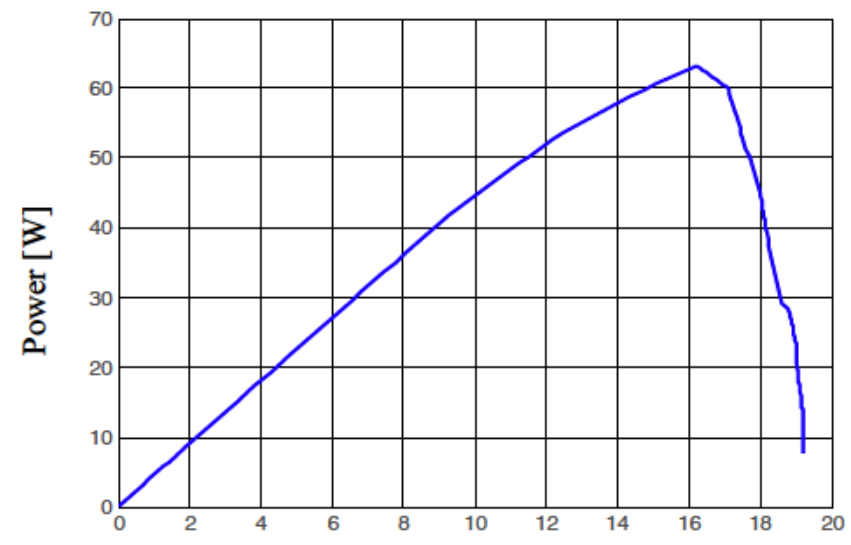

Voltage [V]

b

Figure 9: Measured characteristic of a single PV module. (a) I-V curve. (b) P-V curve.

Figure 10 presents the control signal which drives the power transistor of the boost chopper. The implemented electronic circuit generates a square wave of variable duty cycle ( $25 \%-75 \%$ ). Also, the switching frequency is also controllable to improve the performance of the dc boost chopper and to force the inductor current to be continuous. So, the current drawn from the $P V$ is also continuous.

The output voltage of the chopper which feeds the dc pump and charges the battery bank is plotted in Figure 11. The measured steady state dc voltage is 28 V.

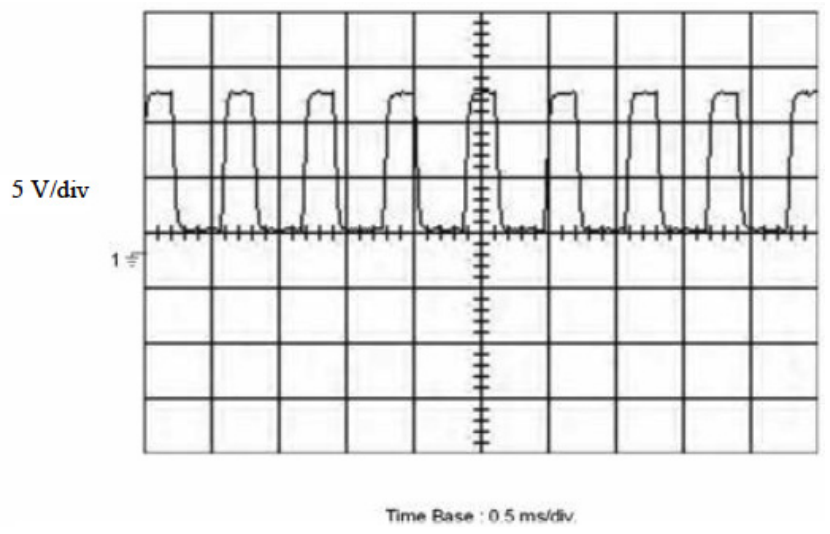

Figure 10: Switch control signal of the boost chopper.

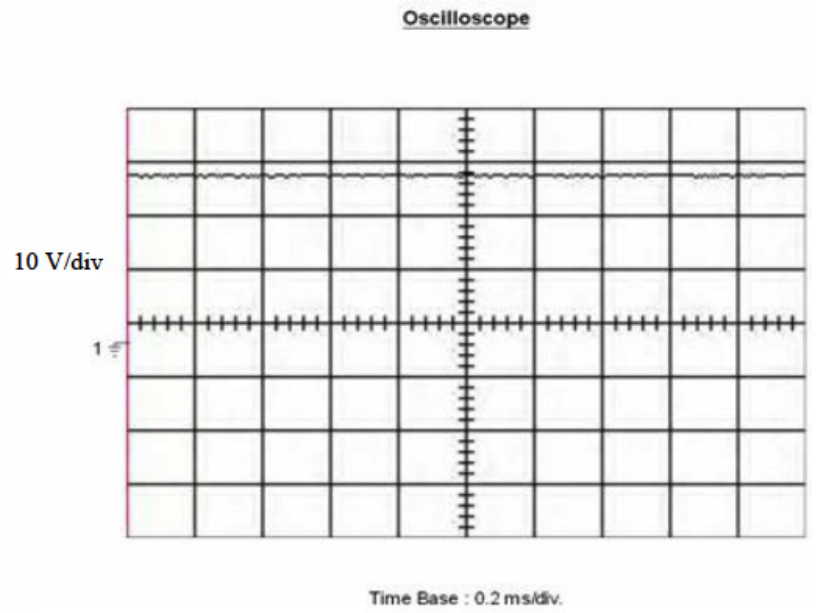

Figure 11: Output voltage of the boost chopper.

In Figure 12 some photos of the implemented prototype are presented. The artificial light source changes the irradiance level to study the performance of the unit inside the laboratory. As shown, the level of irradiance can be adjusted between $100 \%-0 \%$ in four step each of $25 \%$ of the full irradiance. The observed flow rate of the desalinated water is around 1 Litter/minute which is sufficient for home drinking requirements.

\section{CONCLUSION}

In this paper, a feasibility of utilizing autonomous RO water desalination unit driven by photovoltaic module is investigated to be employed in arid zone as a safe resource of drinking water. Yanbu city is chosen as a case study. The potential of solar energy in Yanbu is initially investigated. It is found that Yanbu has enormous potential to apply solar systems owing to the annual registered data.

Owing to the feasibility study, utilization of small autonomous desalinations unit is applicable and would 
gain the society approval and economically accepted in the case of brackish well water. While in the case of seawater, the capital costs are extremely high and the cost of desalinated water will not be economically feasible unless governmental subsidies are provided to communities near the coastal regions.

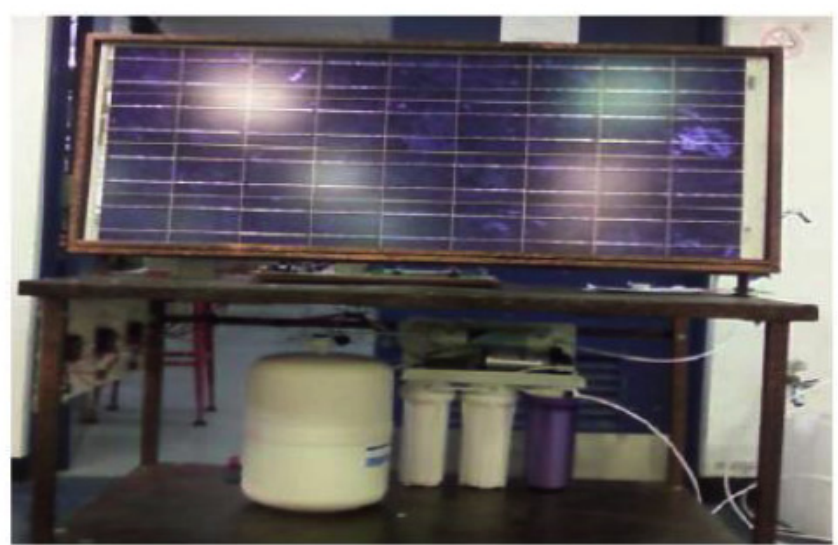

a

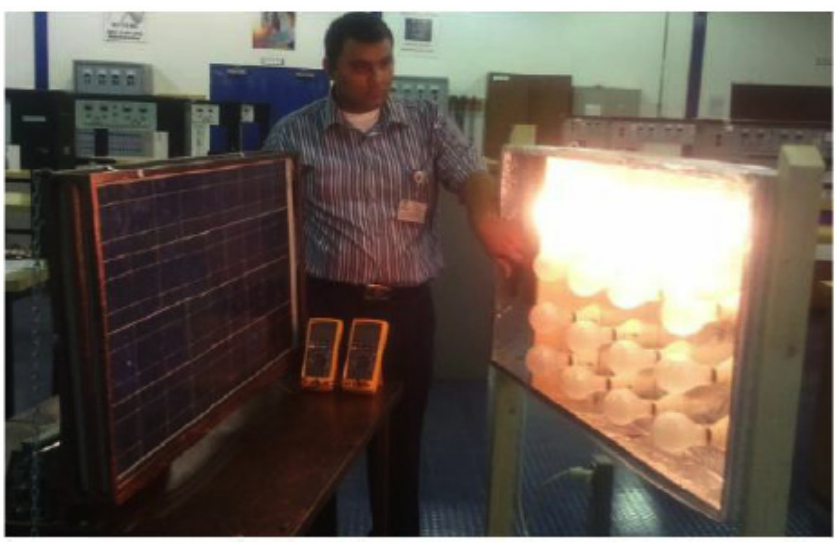

b

Figure 12: a. Experimental prototype of the PV driven water desalination unit. $\mathbf{b}$. Testing of the PV module inside the lab.

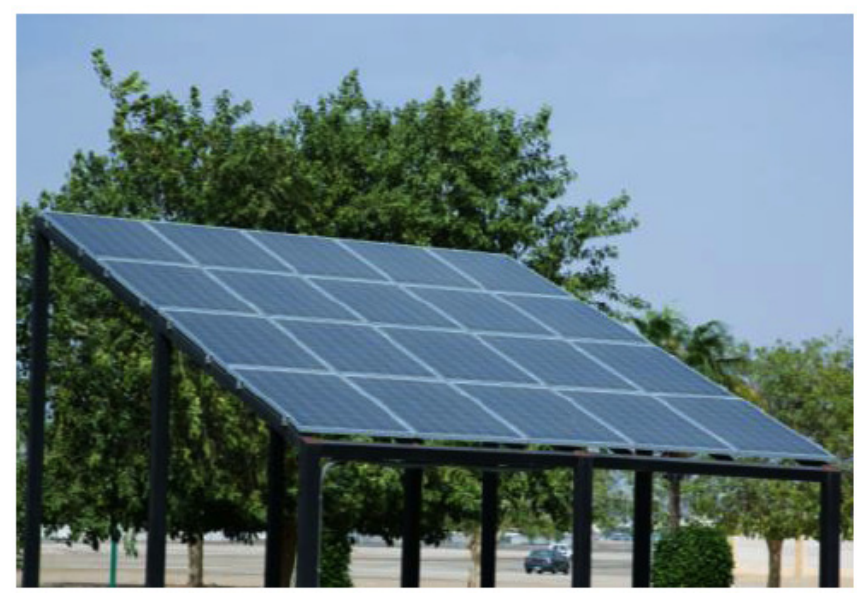

Figure 13: Installed 4kW PV modules at the Center for Renewable Energy.

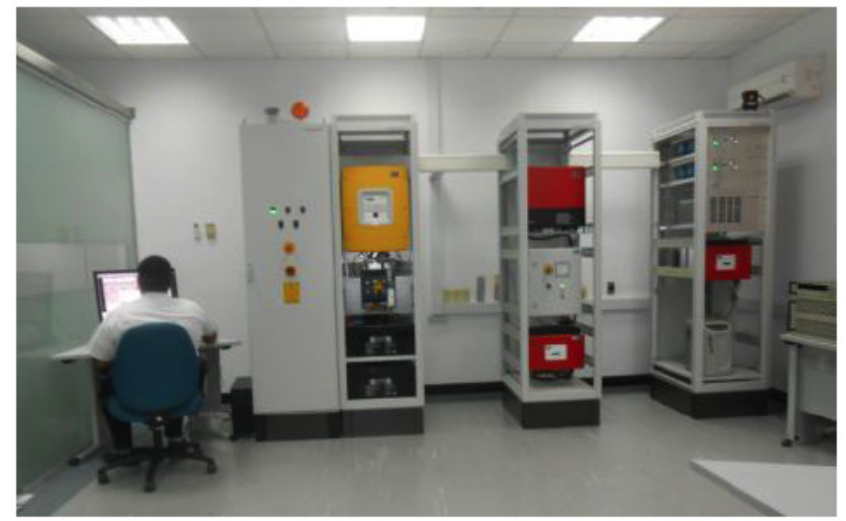

Figure 14: Center for Renewable Energy Installed at Colleges and Institutes sector of Royal Commission at Yanbu, KSA.

In addition, the study indicated that for the same water consumption amount, the utilization of energy storage version (day-night) adds additional capital cost for batteries and extra running cost for battery replacement, which make the unit price not only incompetent with day-only unit but also with conventional units powered by diesel generator (fossil fuel) owing to the low prices of fuel in the kingdom.

However, the cost analysis shows that the price of the produced water per cubic meter of day-night unit is similar to that produced from the day-only unit provided that the day-night unit operates theoretically for a longer period of $50 \%$.

Therefore, Governmental subsidies programs should be initiated and offered in order to encourage the utilization of such green systems.

\section{ACKNOWLEDGEMENTS}

The authors are grateful to Research Center of Colleges and Institutes Sector-Royal Commission at Yanbu for the support to carry out and publish this study.

\section{REFERENCES}

[1] Organization for Economic Cooperation and Development (OECD) report. OECD Environment Outlook to 2030, Paris 2008.

[2] Joyce A, Loureiro D, Rodrigues C, Castro S. Small reverse osmosis units using PV systems for water purification in rural places. Journal of Desalination 2001; 137: 39-44.

[3] Fiorenza G, Sharma VK, Braccio G. Techno-economic evaluation of a solar powered water desalination plant, Solar Desalination for the $21^{\text {st }}$ Century, 33-41, Springer 2007.

[4] Chaibi MT, Bourouni K. Development of solar desalination systems concepts for irrigation in arid areas conditions, Solar Desalination for the $21^{\text {st }}$ Century, pp. 19-32, Springer 2007.

[5] United Nations world water development report, Water in a changing world 2009. 
[6] Mahmoud MM. Solar Electric Powered Reverse Osmosis Water Desalination System for the Rural Village Al Maleh: Design and Simulation. Int Journal of Solar Energy 2003; 112.

[7] Tzen E, Morris R. Renewable energy sources for desalination. Solar Energy 2003; 75: 375-379.

[8] Azab M. Optimal Power Point Tracking For Stand-Alone PV System Using Particle Swarm Optimization. IEEE ISIE International Symposium on Industrial Electronics Italy, July 2010; 10: 969-973.

http://dx.doi.org/10.1109/isie.2010.5637061
[9] Esram T, Chapman PL. Comparison of Photovoltaic Array Maximum Power Point Tracking Techniques. IEEE Trans Energy Conversion 2007; 22: 439-449.

[10] Banat F, Qiblawey H. Membrane desalination driven by solar energy, Solar Desalination for the $21^{\text {st }}$ Century 2007; pp. 271-291.

[11] Azab M. Parameters Estimation of PV Module without Experimental Measurements Using Particle Swarm Optimization, 39th IEEE IECON, pp. 7004-7008,VienaAustria 2013. 